ANATOLIA Anatolia Antiqua

ANTIQUA

Revue internationale d'archéologie anatolienne

XXIV | 2016

Varia

\title{
Field Surveys in Ardahan in 2015
}

Sami Patacı and Ergün Laflı

\section{(2) OpenEdition}

\section{Journals}

Electronic version

URL: http://journals.openedition.org/anatoliaantiqua/387

DOI: 10.4000/anatoliaantiqua.387

Publisher

IFEA

Printed version

Date of publication: 1 May 2016

Number of pages: 281-297

ISBN: 9782362450648

ISSN: 1018-1946

\section{Electronic reference}

Sami Patacı and Ergün Laflı, "Field Surveys in Ardahan in 2015", Anatolia Antiqua [Online], XXIV | 2016,

Online since 11 December 2018, connection on 16 February 2021. URL: http://

journals.openedition.org/anatoliaantiqua/387 ; DOI: https://doi.org/10.4000/anatoliaantiqua.387

Anatolia Antiqua 


\section{ANATOLIA ANTIQUA ESKI ANADOLU}

\section{XXIV}

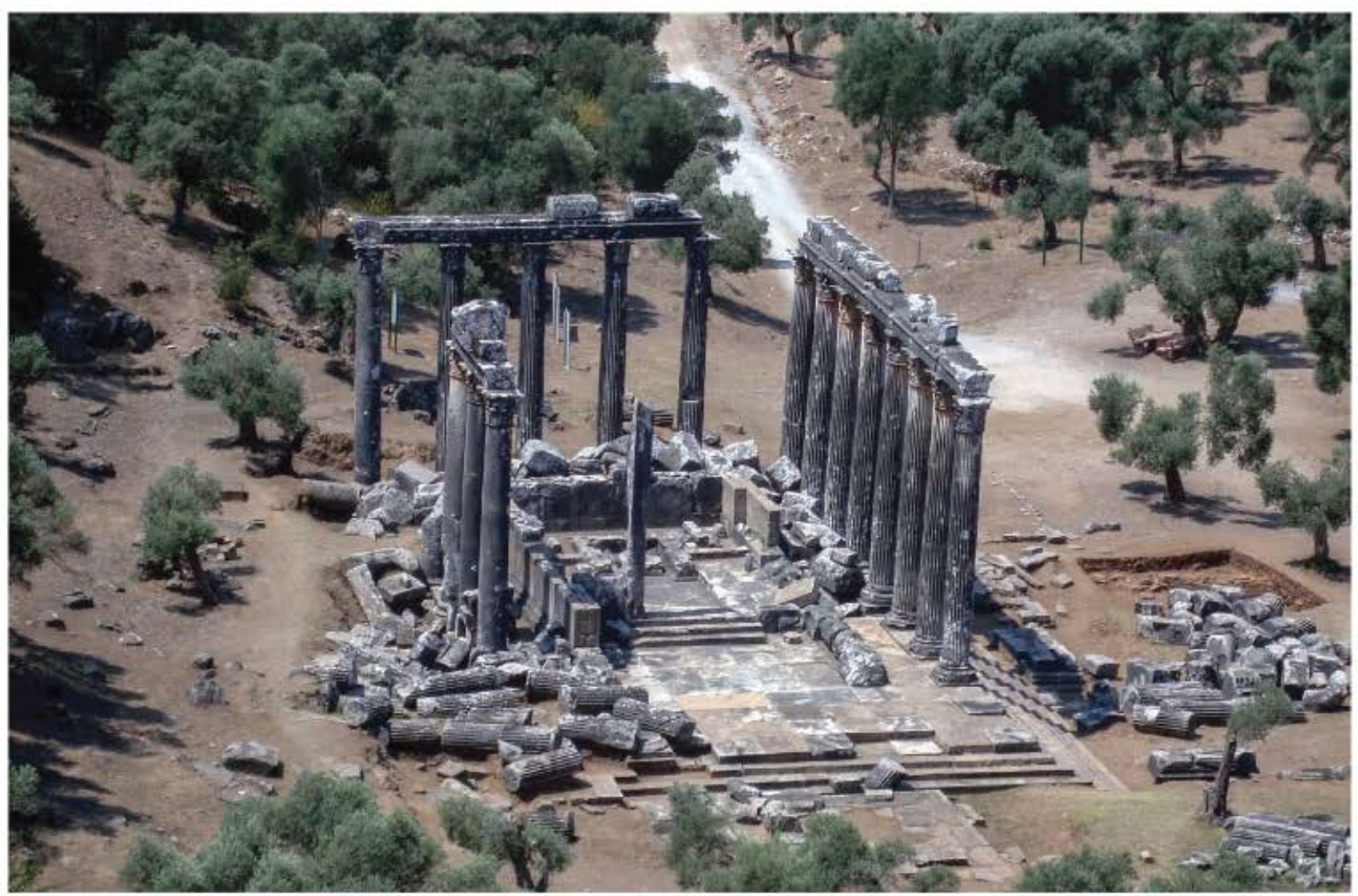

INSTITUT FRANÇAIS D'ETUDES ANATOLIENNES GEORGES-DUMEZIL

CNRS USR 3131

DE BOCCARD 


\section{TABLE DES MATIERES}

Ergul KODAS,

Le surmodelage du crâne au Néolithique au Proche-Orient : techniques de surmodelage et

expérimentations

Isabella CANEVA et Eric JEAN,

Mersin-Yumuktepe : une mise au point sur les derniers travaux

Turan EFE et Bérengère PERELLO,

Second Millenium site distribution and pottery of Inland Northwestern Anatolia

Antoine PEREZ,

Amida 6 : Antiochos IV, le "Hanigalbat" et la Sophène

Ergün LAFLI et Hadrien BRU,

Inscriptions et monuments funéraires gréco-romains d'Anatolie occidentale

Oğuz TEKİN et Aliye EROL-ÖZDİZBAY,

Coins from Allianoi excavations: Campaign of 2001

Nuran ŞAHIN,

Etude iconographique des monnaies autonomes frappées par Colophon-sur-Mer :

nouveaux acquis

Vera SAUER,

Konventionelle Individualität. Zur Münzprägung nordanatolischer Städte in der römischen

Kaiserzeit

Oğuz TEKIN,

Balance weights in the collection of the Anatolian Civilizations Museum in Ankara

\section{CHRONIQUES DES TRAVAUX ARCHEOLOGIQUES EN TURQUIE 2015}

Çiğdem MANER,

Preliminary report on the third season of the Konya-Ereğli Survey (KEYAR) 2015

Dominique BEYER, Isabelle CHALIER et Françoise KIRNER,

Rapport préliminaire sur les travaux de la mission archéologique de Zeyve Höyük-Porsuk 2015 ...

Sami PATACI et Ergün LAFLI,

Field surveys in Ardahan in 2015

Jean-Charles MORETTI avec la collaboration de Nicolas BRESCH, Isabel BONORA,

Jean-Jacques MALMARY et Olivier RISS,

Claros, le temple d'Apollon : travaux réalisés en 2015

Serdar Hakan ÖZTANER,

La basilique civile de Nysa du Méandre

Abuzer KIZIL, Koray KONUK, Patrice BRUN, Laurent CAPDETREY, Raymond DESCAT,

Pierre FROHLICH, Didier LAROCHE, Enora LE QUERE, Francis PROST, Baptiste VERGNAUD,

Eurômos : rapport préliminaire sur les travaux réalisés en 2015

O. HENRY et E. ANDERSON, Chr. BOST, Ö. ÇAKMAKLI, F. CEDERLING, A. COMMITO,

M. CORMIER-HUGUET, A. COUTELAS, A. DOLEA, D. ERGENÇ, A. FRECCERO,

A. FREJMAN, P. LEBOUTEILLER, F. LESGUER, D. LÖWENBORG, V. LUNGU,

Fr. MARCHAND-BEAULIEU, A. SITZ, P. DE STAEBLER, B. VERGNAUD, 


\section{Sami PATACI* et Ergün LAFLI**}

\section{FIELD SURVEYS IN ARDAHAN IN 2015}

The Turkish province of Ardahan situates in a relatively neglected area of archaeological research in northeastern Turkey. The dynamics of cultural development in this region at the northern frontier of the Near Eastern archaeology are still problematic, as its archaeology has so far received very limited attention, especially when compared with other borderlands in eastern Turkey and Transcaucasia. Our multi-period regional landscape surveys, begun in 2013, aimed to analyze the existence of different archaeological communities and cultural regionalism of Ardahan. Thus, the main scope of our survey season conducted in 2015 was to produce maps of surface features in Ardahan and to analyze a broad range of relationships concerning intensive stock farming and cultural development in ancient times. For widening archaeological horizons of this region we focused primarily on settlement patterns, regional analysis and landscape archaeology of the province Ardahan.

The fieldwork in 2015 has taken place in the central district of Ardahan, as in the seasons of 2013 and 2014. It included villages of Kartalpınar, Yaylacik, Kocaköy, Alagöz, Çamlıçatak and Ölçek and their neighbourhood (Map 1). Archaeological field researches have been conducted in the high plateau site of Tekdoruk in Kartalpınar, höyük site of Kartalpınar, watchtower site at Kocaköy and the archaeological sites in the villages of Alagöz and Çamlıçatak for the first time. A Second millennium B.C. site and cemetery in Kartalpınar, discovered in last season, is also examined.

\section{HIGH PLATEAU SITE OF TEKDORUK IN KARTALPINAR}

This archaeological site is located on the peak of the hill of Tekdoruk that is located $3.5 \mathrm{~km}$ to the northwest of the village Kartalpınar village and 7 $\mathrm{km}$ to the north of the city center (Map 1). There is a group of ruined remains on the peak of this hill altitude of which is about $2435-2450 \mathrm{~m}$. Conditions of these finds are similar to the ones in the high plateau site of Çeğilli. The architectural remains on the peak are hardly detectable. A circular wall row surrounds the natural terrace on the peak and there is a round-planned structure situating in the center. As in Çeğilli no in situ walls are preserved in the center of the field (Fig. 1). In situ remains which were surrounding the site as an outer wall can sporadically be observed here and rubble piles belonging to the wall constructions are also visible (Fig. 2-3). It is clarified that the bounding wall is about 30-40 $\mathrm{m}$ in diameter at minimum. Yet, no pottery for a better date of the archaeological site could be determined. Most of these archaeological sites on the peaks of hills in the plateau of Ardahan should be dated to the Bronze Ages.

\section{KARTALPINAR HÖYÜK AND L-PLANNED ARCHITECTURAL REMAINS}

A further archaeological site in the neighbourhood of the village Kartalpınar is a höyük site. It is located $1.2 \mathrm{~km}$ southwest to the village, in a point with the altitude of $1819 \mathrm{~m}$, close to the terrain where villagers from Kartalpinar have their agricultural crop land (Map 1). This site locates just $150 \mathrm{~m}$ north of Kura River Valley. Höyük site lies $300 \mathrm{~m}$ in east-west and $150 \mathrm{~m}$ in north-south directions (Fig. 4). Surface pottery exhibits the features of the Second Millennium B.C. (Fig. 5), with a small portion of Early Iron Age pottery.

There is a further archaeological site $200 \mathrm{~m}$ east of Kartalpınar Höyük. Its remains are L-planned and located partially on the edge of the cliff, facing

\footnotetext{
*) Ardahan Üniversitesi, İnsani Bilimler ve Edebiyat Fakültesi, Arkeoloji Bölümü, Yenişey Kampüsü, Merkez, TR-75000 Ardahan, Turkey; <samipataci@hotmail.com>.

**) Dokuz Eylül Üniversitesi, Edebiyat Fakültesi, Arkeoloji Bölümü, Tınaztepe/Kaynaklar Yerleşkesi, Buca, TR-35160 Izmir, Turkey; <elafli@yahoo.ca>.
} 


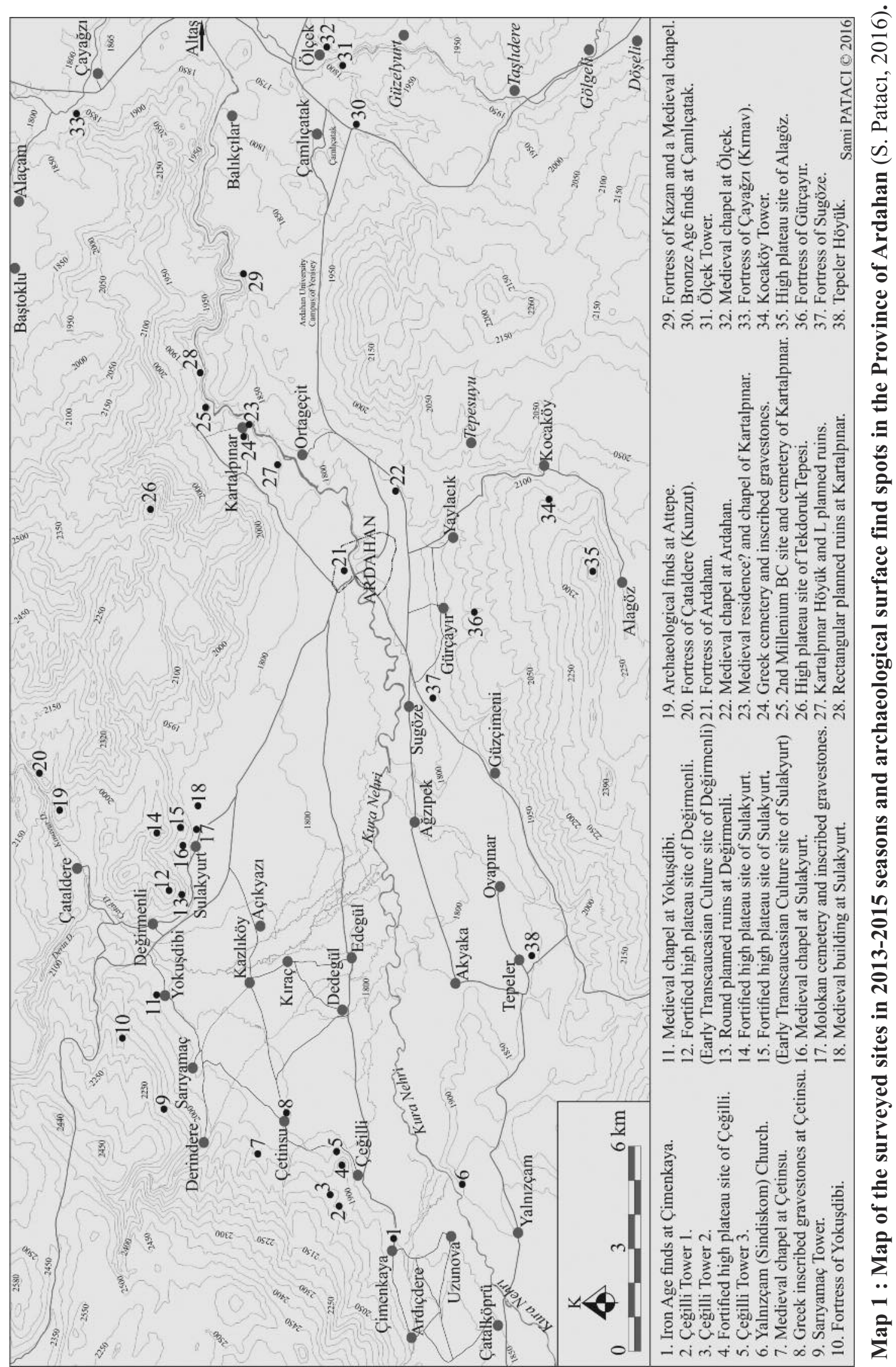



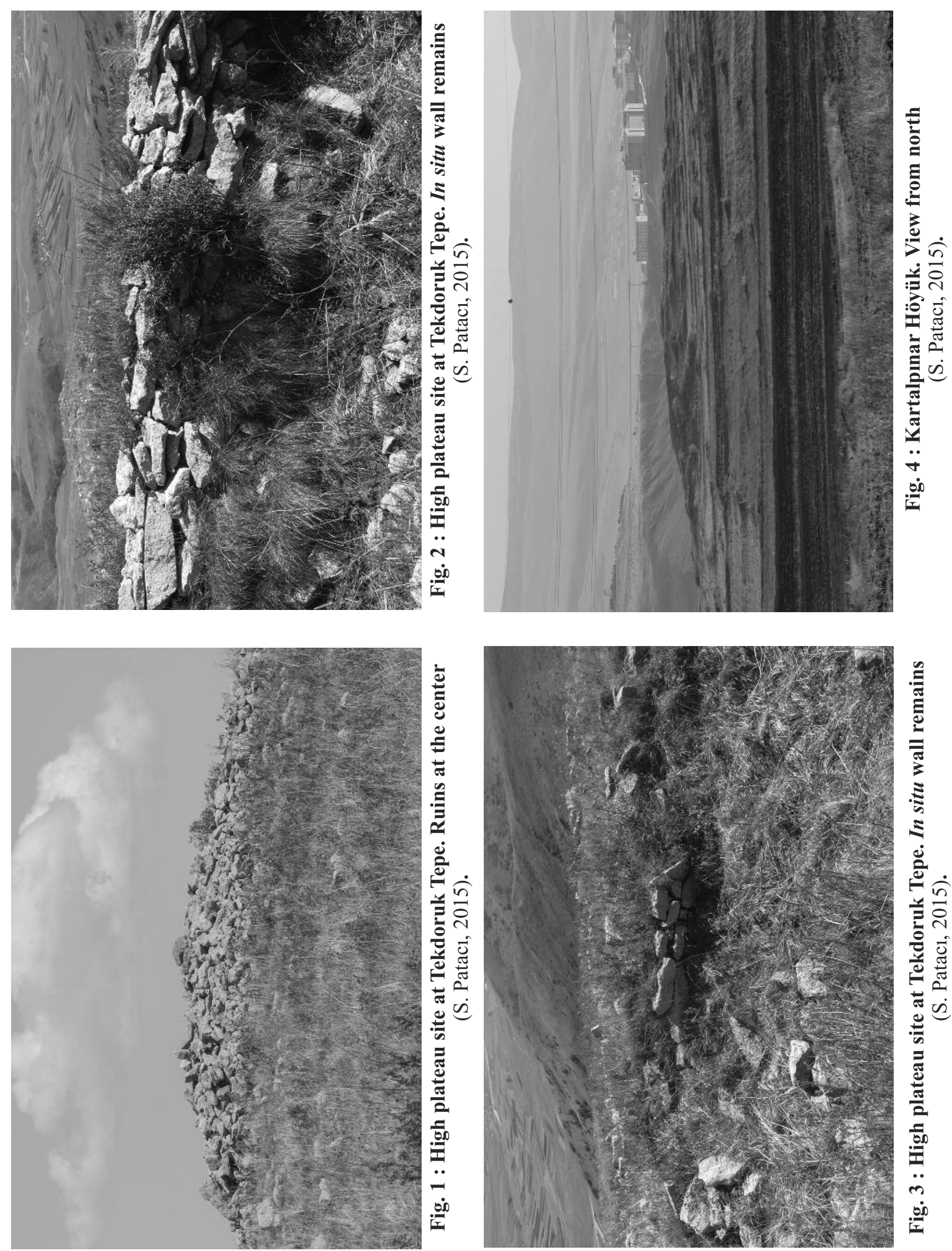


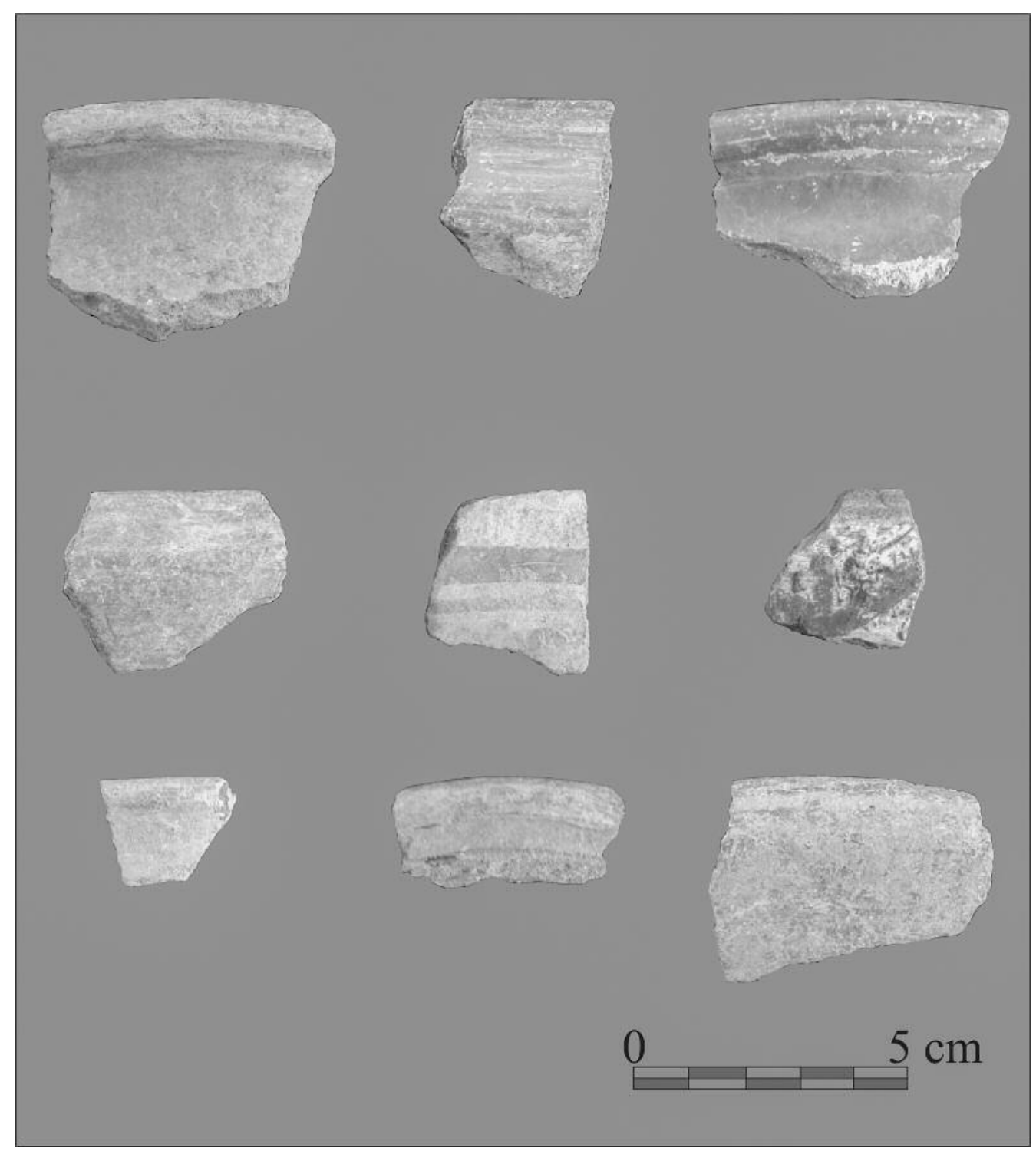

Fig. 5 : Pottery finds from Kartalpınar Höyük (S. Patac1, 2015).

to Kura River (Fig. 6). Western and northern walls exist in an area of $46 \times 42 \mathrm{~m}$ in size. The site is heavily damaged by the villagers of Kartalpınar due to its agricultural use intensively. Because of this, remains are observed only on the northeastern edge and some in situ walls exist in a zone of 1-2 m on the eastern part of the site (Fig. 7). These drywalls were constructed by corbelling small and medium sized stones. Apart from these in situ walls are composed by rubbles and it is possible to find some further in situ walls under this construction rubble. Pottery sherds are scarcely observed on the site. The association between the höyük in Kartalpınar and these architectural remains indicates that these sites were in a close relationship and L-planned ruins must have been used as a pen for animals.

\section{A SECOND MILLENIUM B.C. SITE AND THE CEMETERY OF KARTALPINAR}

In 2015 the survey is continued on the Second Millennium B.C. site and cemetery of Kartalpınar which is discovered in $2014^{1}$. This site, which was in use during the Bronze Age and most probably in the Second Millennium B.C., is located $1.5 \mathrm{~km}$ north of village Kartalpinar (Map 1). During the

1) Patac1 2015a: 73; Patacı and Laflı 2015: 238-240. 


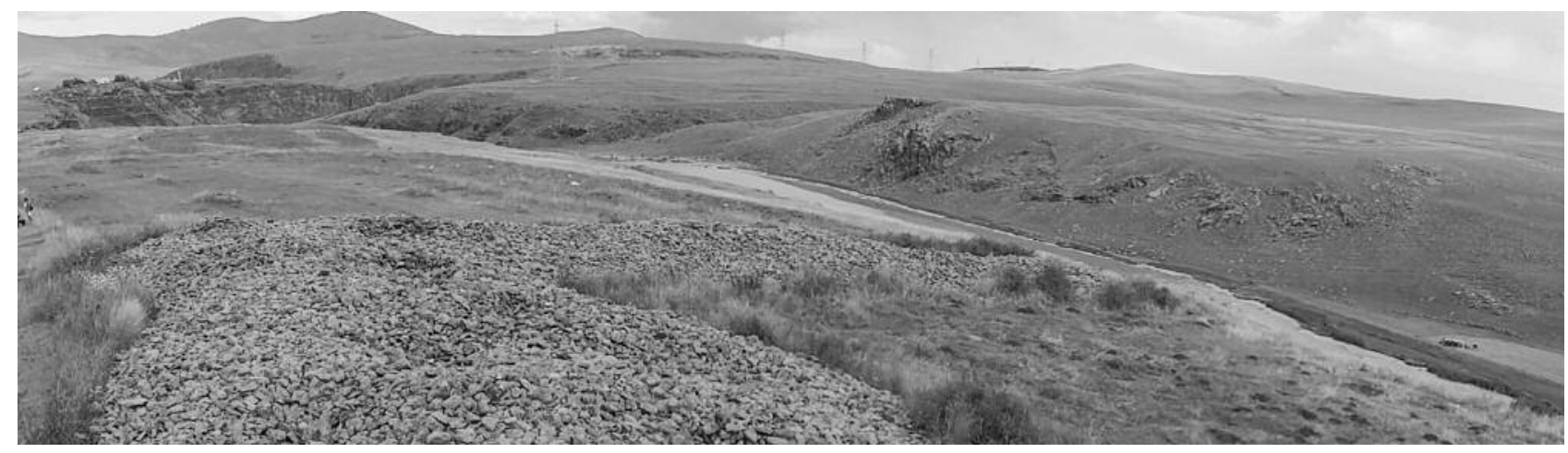

Fig. 6 : L-planned architectural ruins near Kartalpınar Höyük (S. Patac1, 2015).

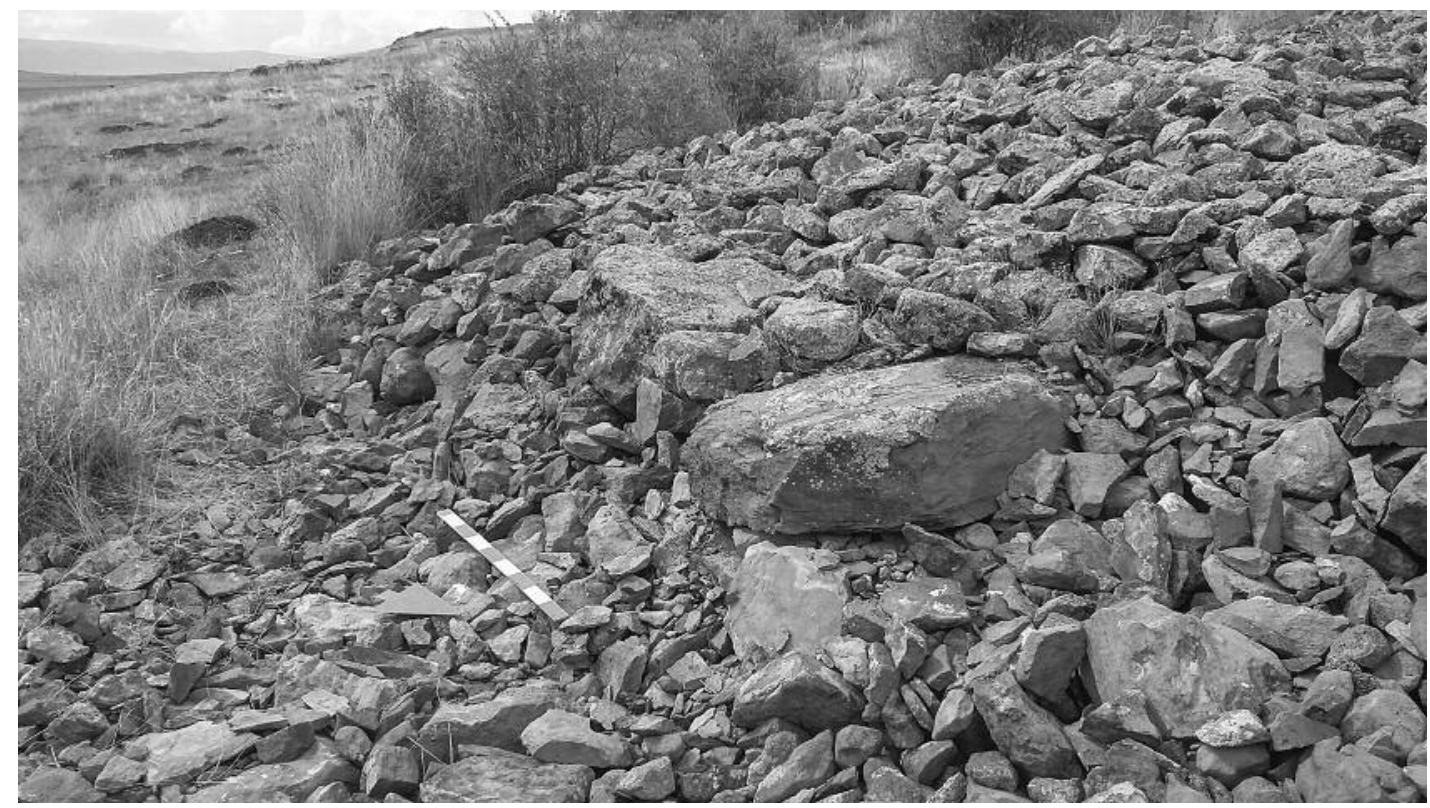

Fig. 7 : L-planned architectural ruins. An in situ wall (S. Patac1, 2015).

2015 season plans of the architectural remains were completely done and limits of the cemetery in its northern side were ascertained (Fig. 8-9). In the surveyed field 16 illicitly excavated pits and locations of 118 graves in total were discovered (Fig. 10). It is clarified that the cemetery covers a zone of $370 \mathrm{~m}$ in north-south directions. Lower part of a possible terracotta figurine was also uncovered (Fig. 11).

\section{HIGH PLATEAU SITE OF ZIYYARET TEPE IN ALAGÖZ}

A "u"-planned high plateau site is discovered in 2015 which is located on the peak of Ziyaret Tepe with an altitude of $2495 \mathrm{~m}$. It situates $1.1 \mathrm{~km}$ northwest of the village Alagöz and $11 \mathrm{~km}$ south of the city center (Map 1). Architectural remains at Zi- yaret Tepe lengthen $48 \mathrm{~m}$ long in east-west directions (Fig. 12-13). At the west edge of the architectural remains a wall lies $17.5 \mathrm{~m}$ to the south. On the east edge of the remains another wall lies $16 \mathrm{~m}$ to the south which makes a "u" plan. In situ wall rows of $1.5 \mathrm{~m}$ height can easily be observed from the western and eastern edges of the area (Fig. 14). The wall bonding is consisted of medium sized stones where drywall technique was used.

In addition three half-round planned rooms exist next to the north wall. Some structures located $10 \mathrm{~m}$ to the northeast of the area are also notified (Fig. 15). Unfortunately, no small finds are recovered from the surface. Compared to other high plateau sites, Ziyaret Tepe in Alagöz is distinguishable because of its plan and round structures. Preliminary results based on architectural analysis show that 


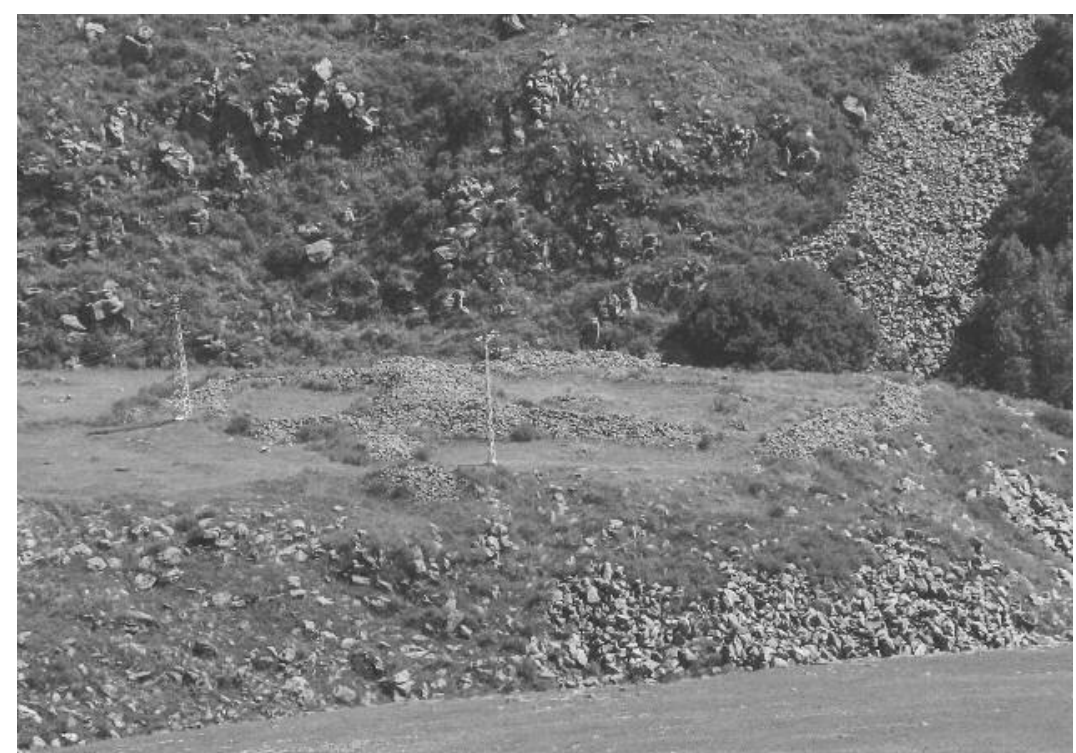

Fig. 8 : Second Millennium site at Kartalpınar. View from west (S. Patacı, 2015).

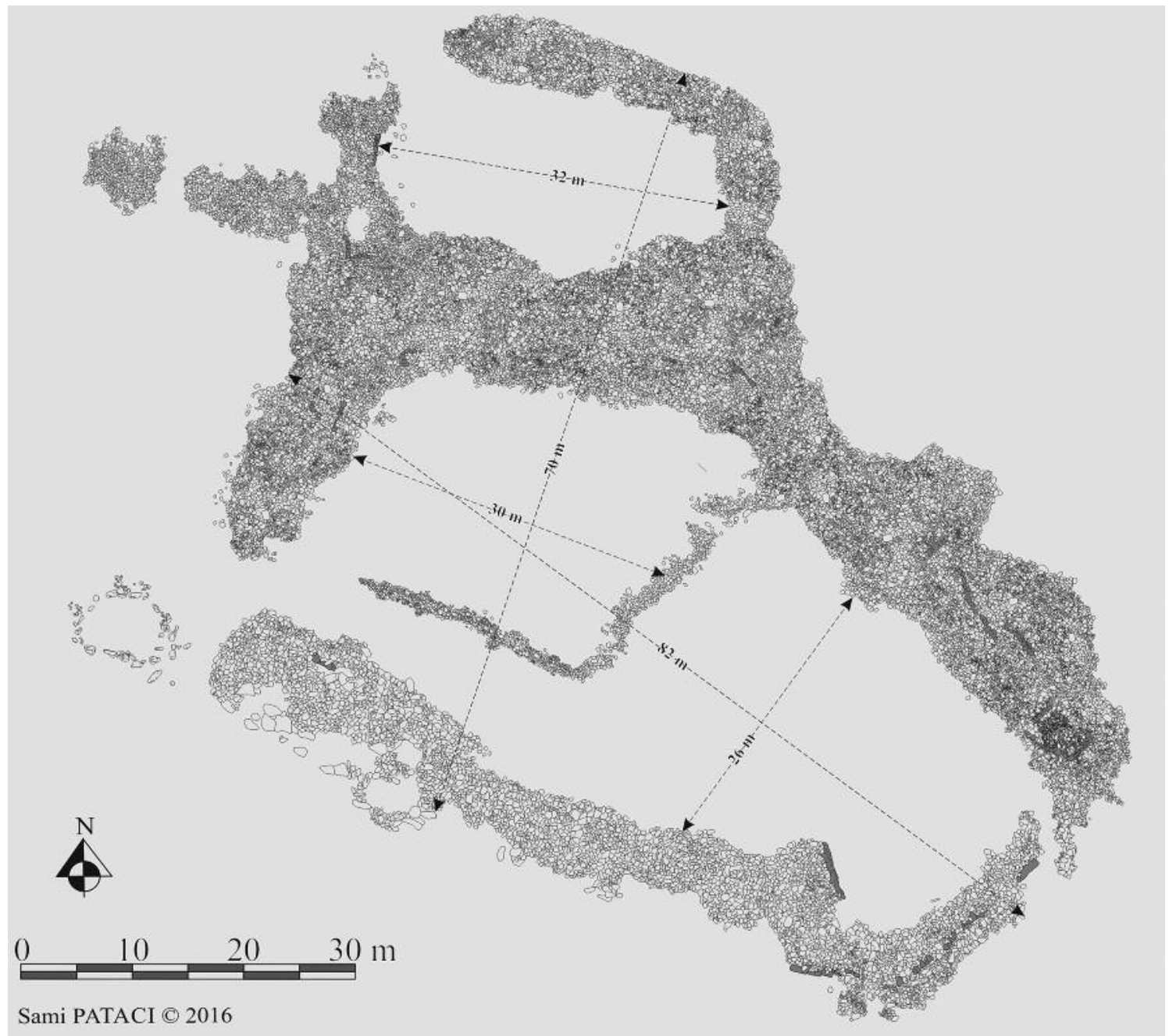

Fig. 9 : Plan of the Second Millennium site at Kartalpınar (S. Patac1, 2016). 


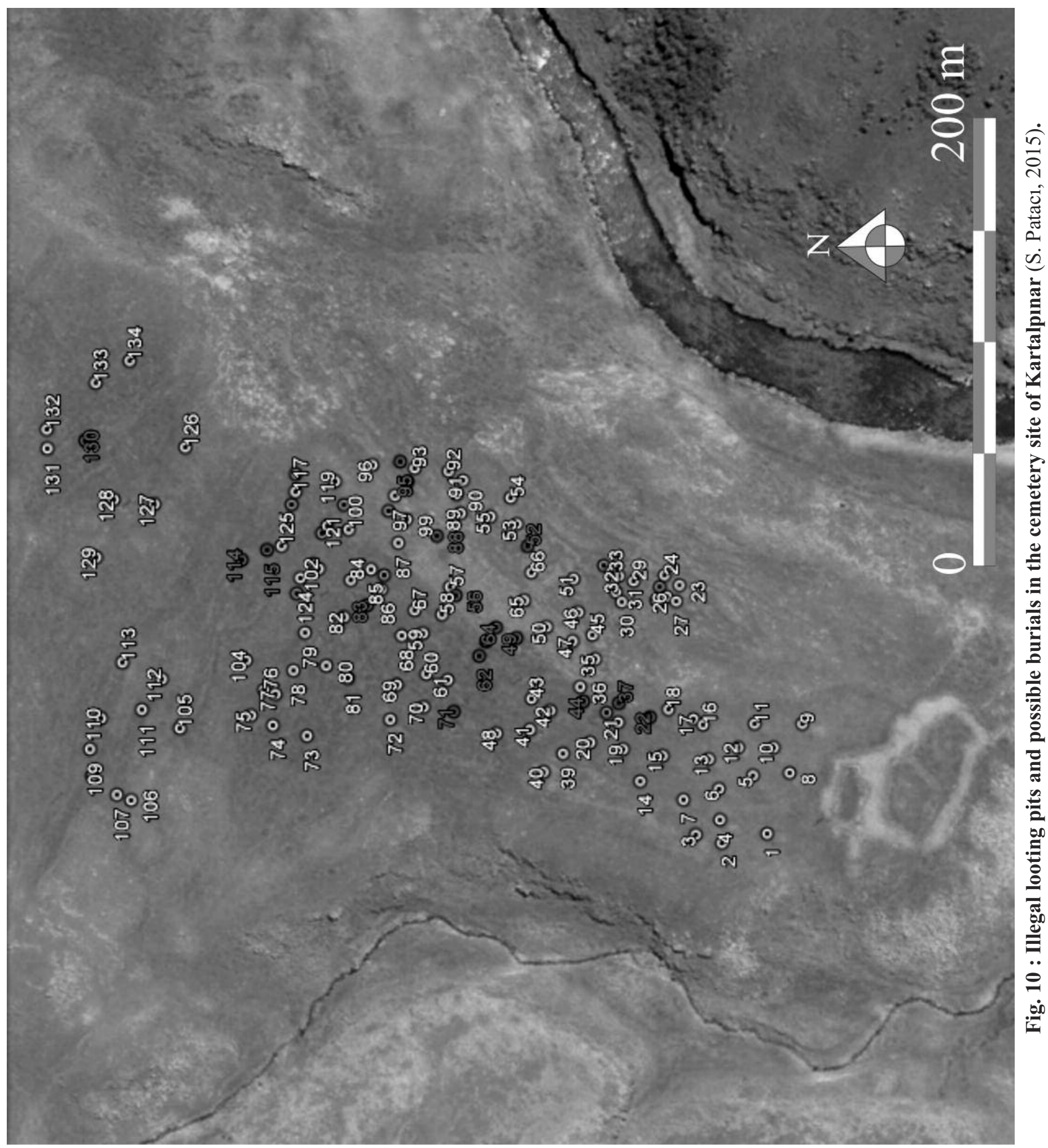




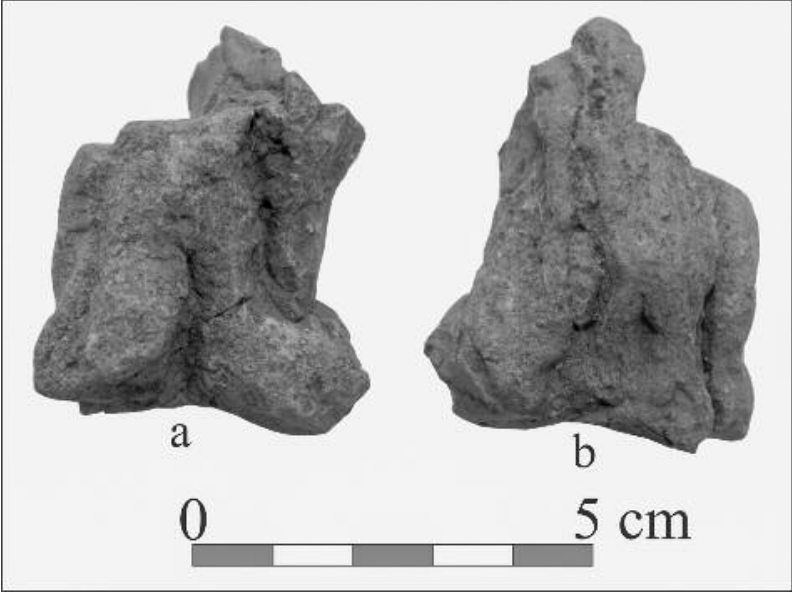

Fig. 11 : Lower part of a possible terracotta figurine (S. Patac1, 2015).

Fig. 12 : High plateau site of Alagöz-Ziyaret Tepe (S. Patac1, 2015).
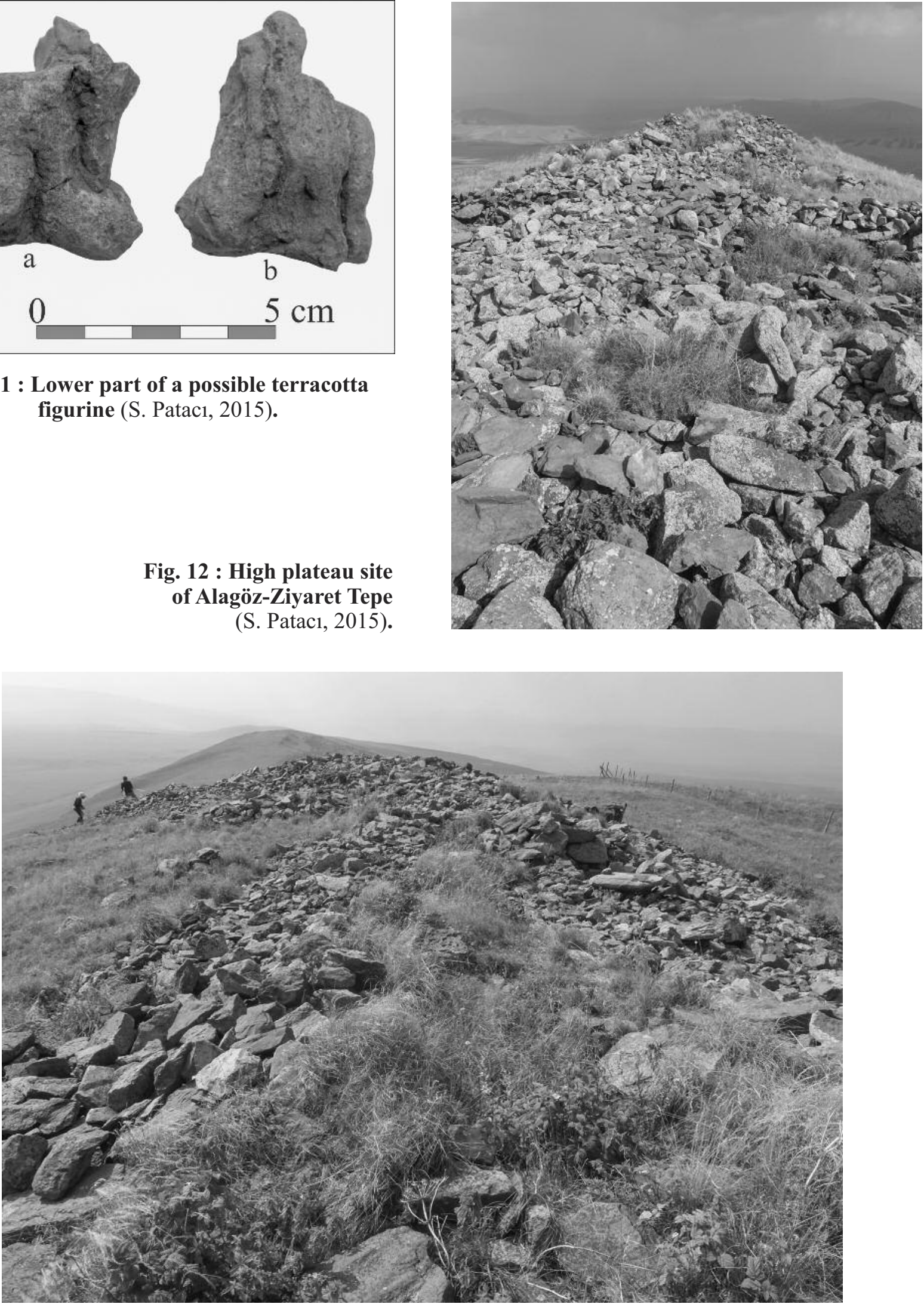

Fig. 13 : High plateau site of Alagöz-Ziyaret Tepe (S. Patac1, 2015). 


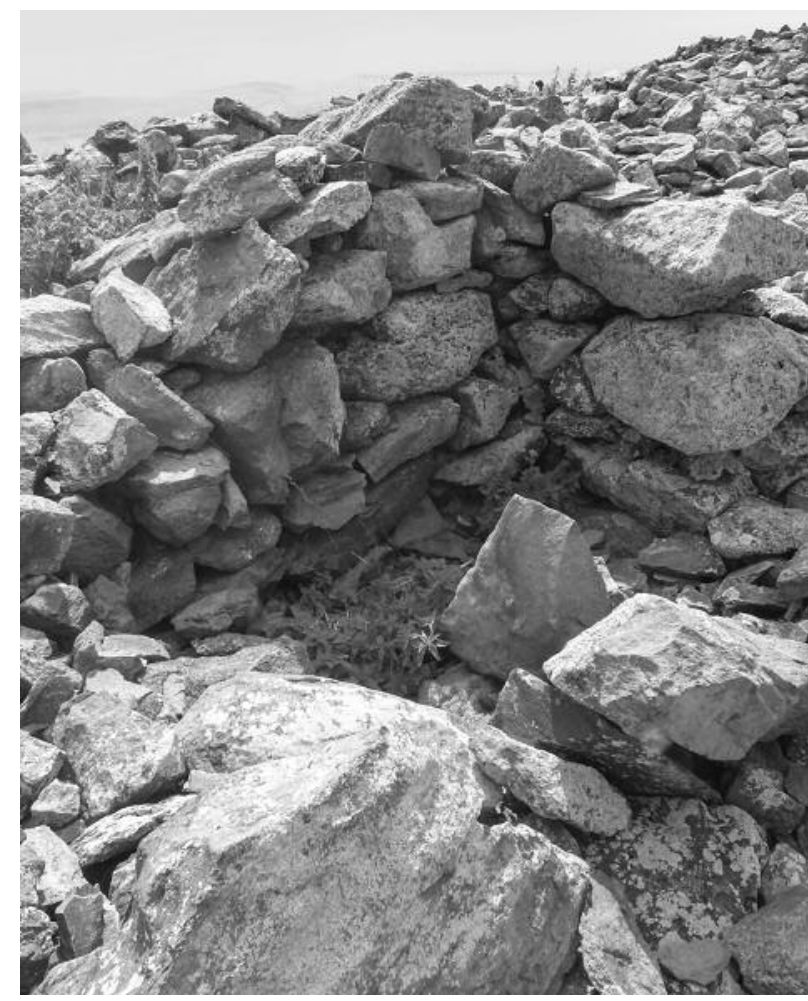

Fig. 14 : An in situ wall from the high plateau site of Alagöz-Ziyaret Tepe (S. Patac1, 2015). this site was in use during the Bronze Ages. Due to the bad weather conditions on this high hill with an altitude of $2500 \mathrm{~m}$, a more detailed fieldwork is postponed to forthcoming seasons.

\section{BRONZE AGE ARCHAEOLOGICAL SITE OF ÇAMLIÇATAK}

A small archaeological site was discovered 300 $\mathrm{m}$ of Çamlıçatak Village, which is located $12 \mathrm{~km}$ southeast of the city center (Map 1). This site has a size of $46 \mathrm{~m}$ in north-south directions and $26 \mathrm{~m}$ in east-west directions. It is located at the junction of Kars, Ardahan, Çıldır, Hanak and Posof highways, just to the eastern edge of the modern asphalt road (Fig. 16). The western part of the site is damaged, because of the construction of modern highway. No architectural remains were discovered; yet a plenty of pottery and obsidian sherds with some worked examples were documented (Fig. 17). Analysed pottery sherds range between Early Transcaucasian and Second Millennium B.C.

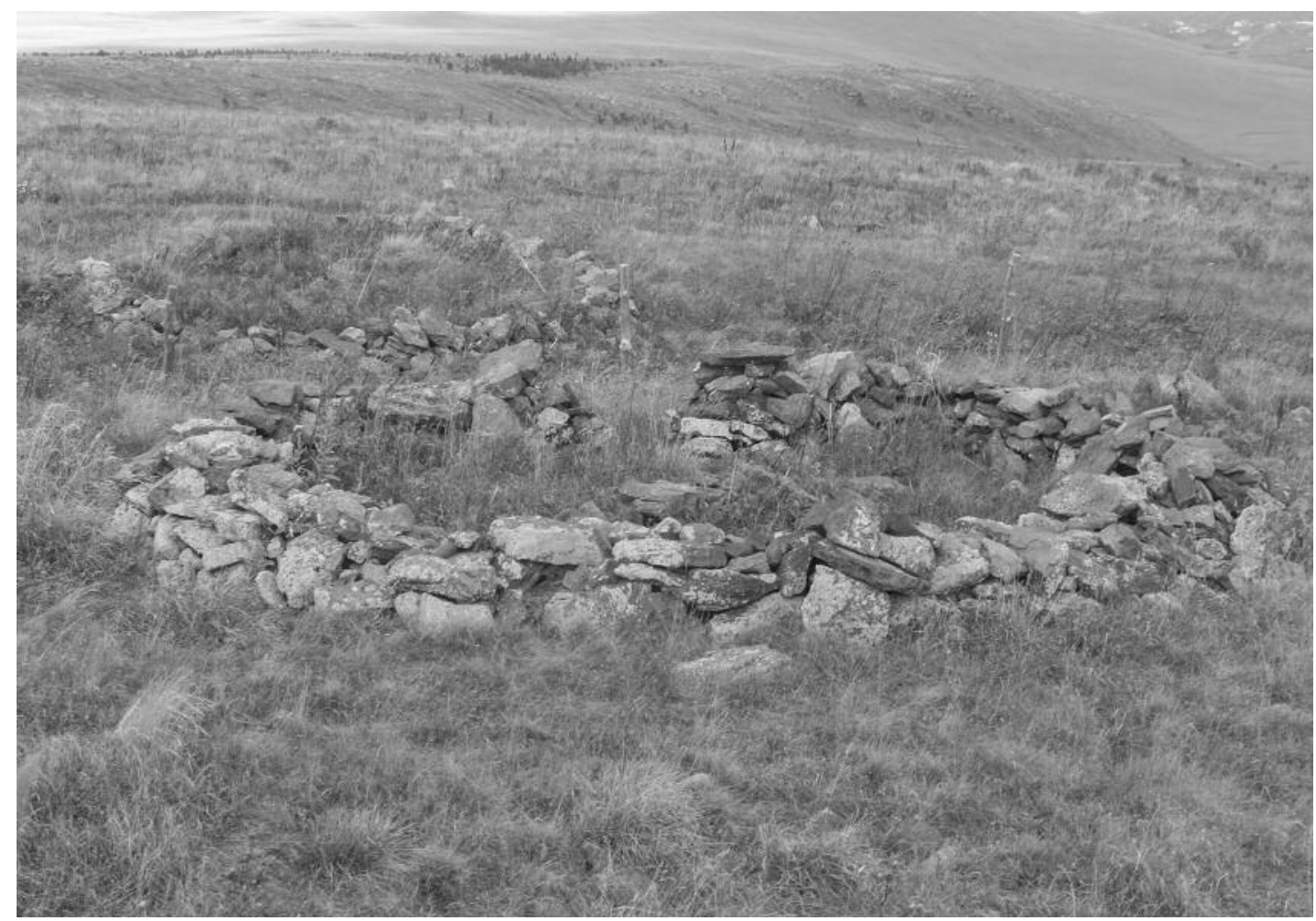

Fig. 15 : Round-planned structures from the high plateau site of Alagöz-Ziyaret Tepe (S. Patac1, 2015). 


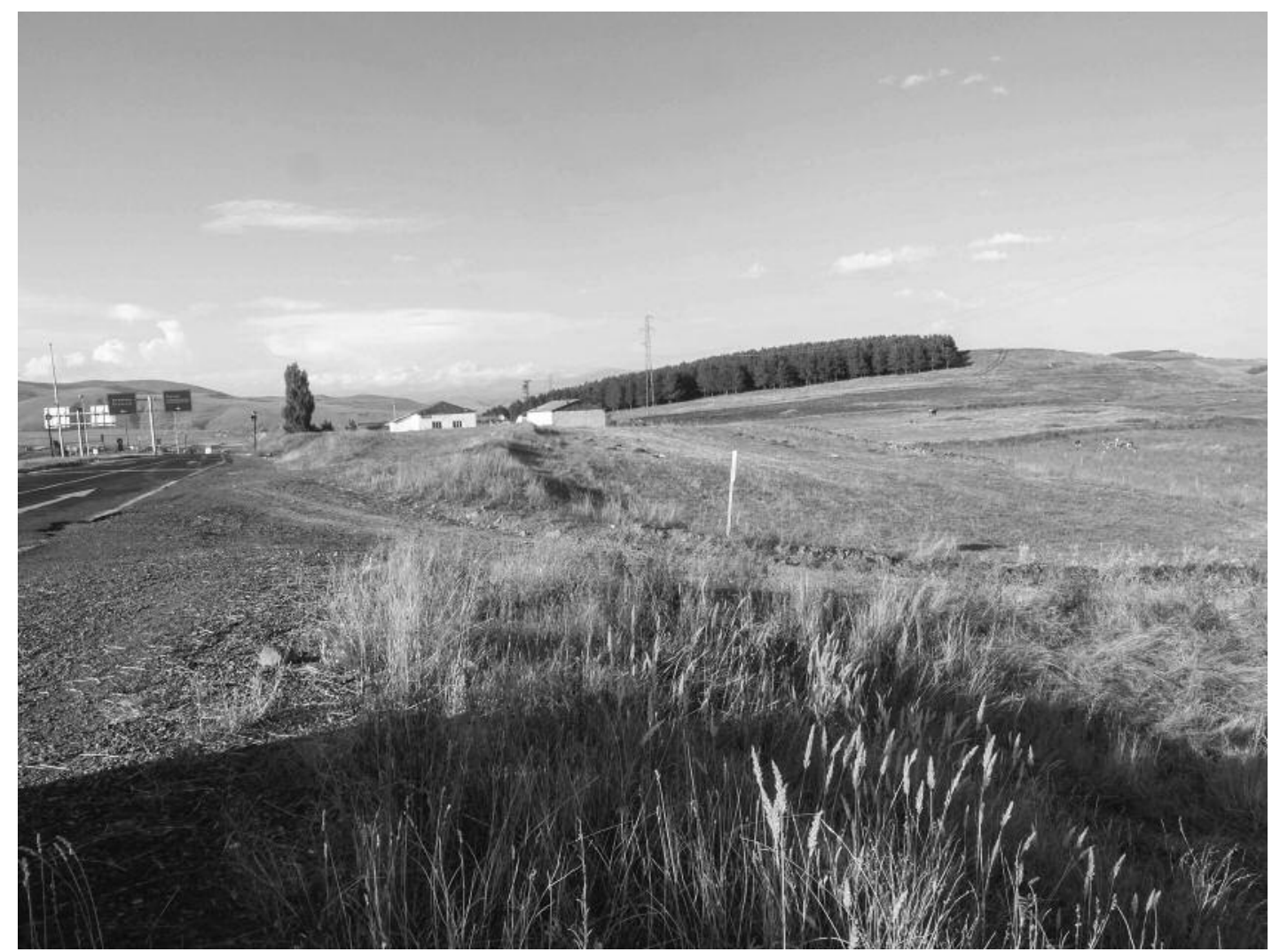

Fig. 16 : Bronze Age site of Çamlıçatak. View from south (S. Patac1, 2015).

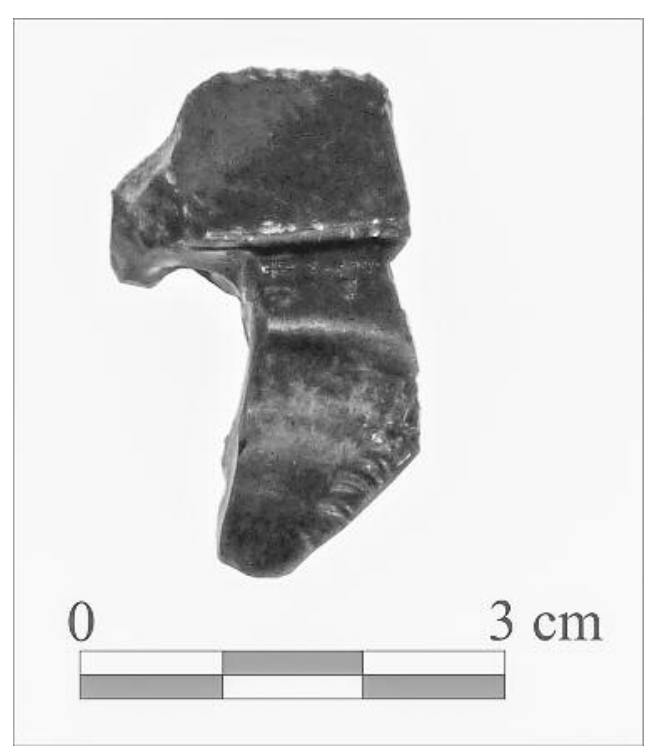

Fig. 17 : A worked obsidian sherd from the Bronze Age site of Çamlıçatak (S. Patacı, 2015).

\section{ÖLÇEK TOWER}

Ölçek Tower is located on a rocky hill called as "Ziyaret Tepe" by the locals, just south of Ölçek Village and $15 \mathrm{~km}$ east of the city center (Map 1). Taşlidere stream flowing through the village surrounds this hill from the west, north and east. This archaeological site was visited for the first time in course of a field survey in $1987^{2}$. In a later research in 1999, this site was named as "Fortress of Ölçek Village", based on the statements of the locals ${ }^{3}$. Yet, as a result of 2015 survey executed in the area, it is clarified that these remains were not belonging to a fortress, but to a tower. Architectural remains in the research area consist only of a tower (Fig. 18-19).

The tower has a rectangular plan (Fig. 20) and is located in northwest-southeast directions. On the northern edge of the tower there is an almost rectangular room of $4.1 \times 3.2 \mathrm{~m}$ in size. Total space of the architectural finds is about $13 \times 11 \mathrm{~m}$ and the

2) Güneri 1992: 162.

3) Gündoğdu 2000: 52-55. 


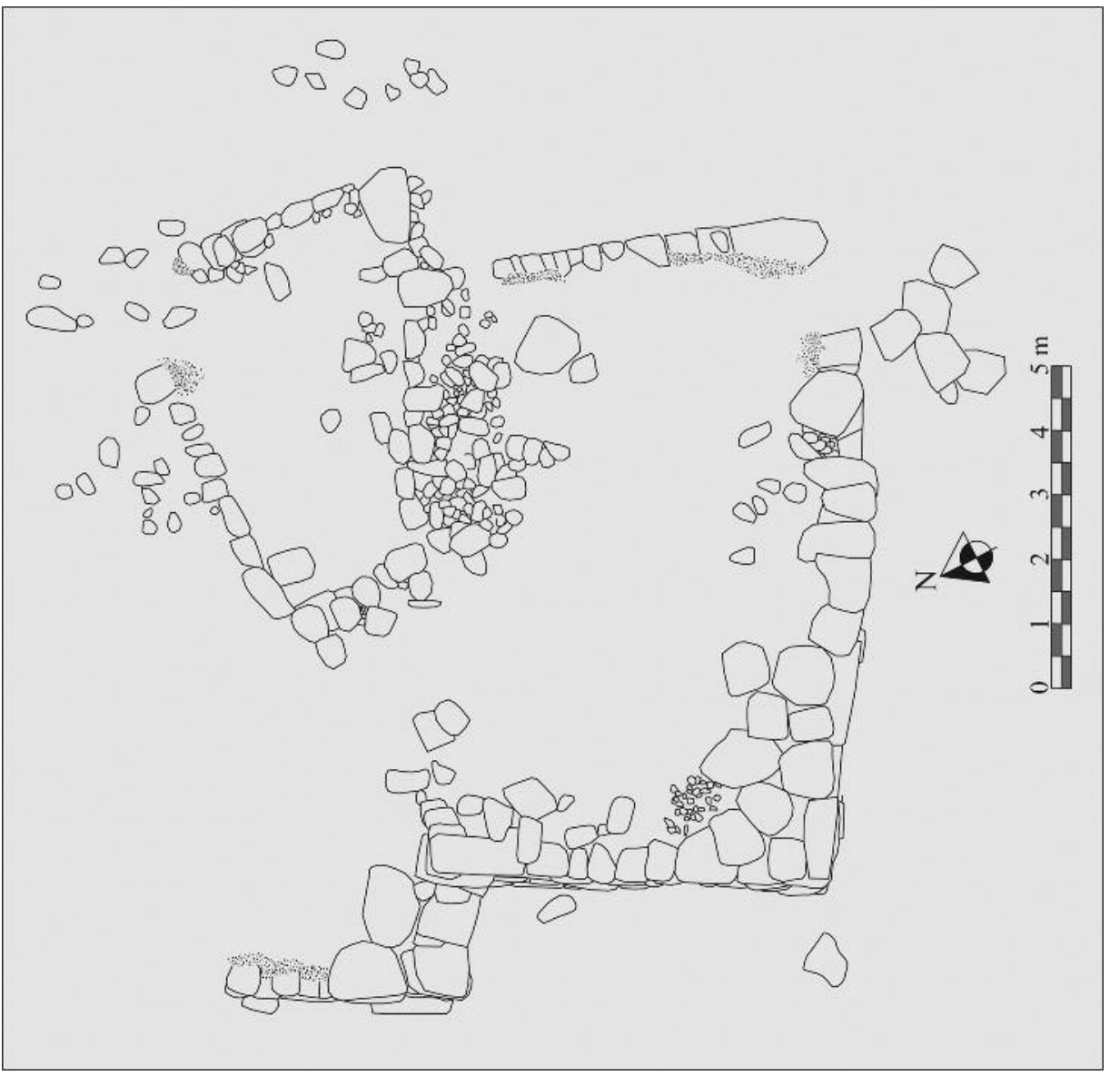

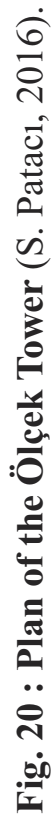
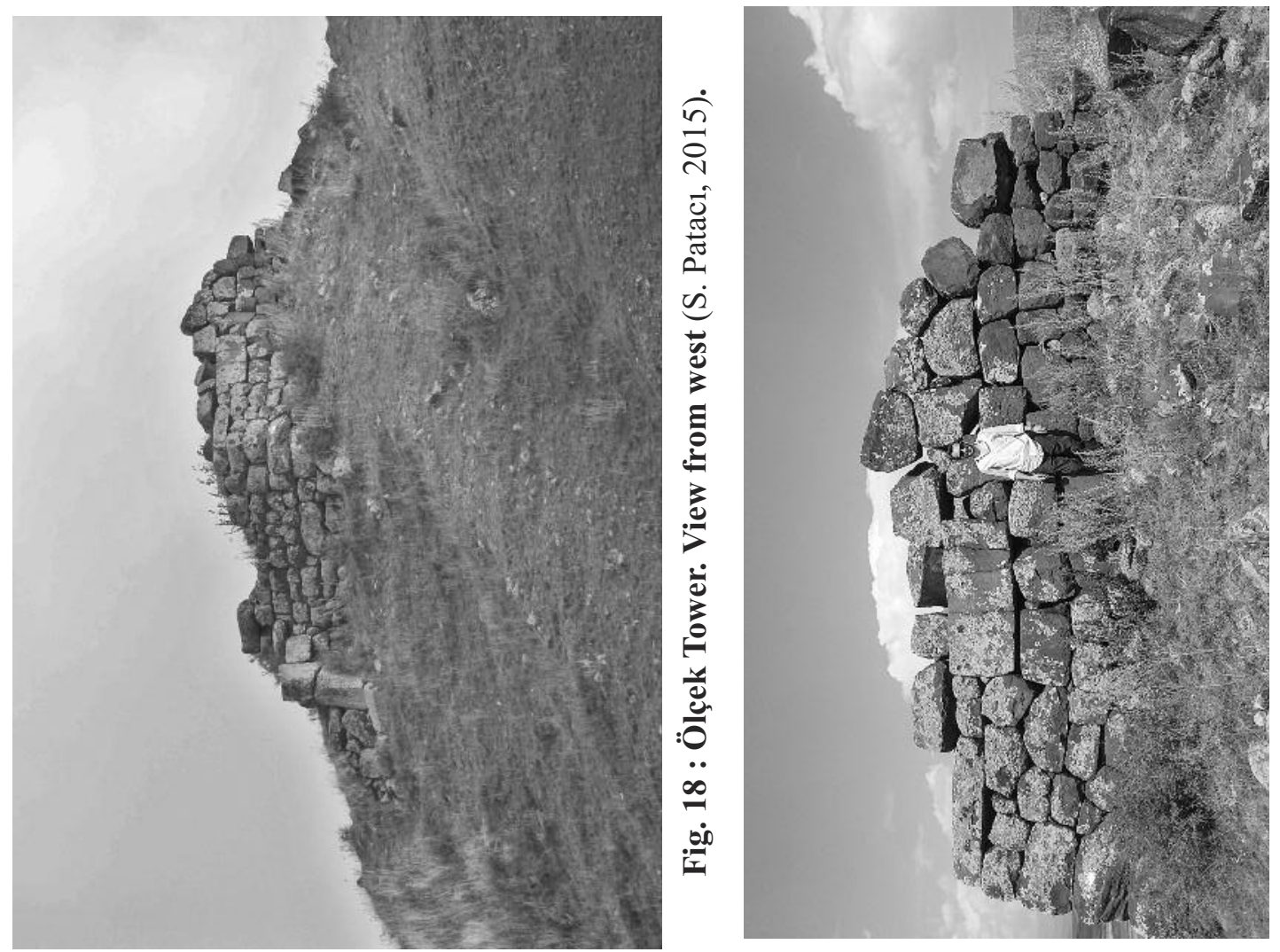
preserved height of the tower is $2.7 \mathrm{~m}$. The tower was built by embarking medium sized and cyclopean stones in drywall technique. Few pottery fragments documented around the tower belong to the Soecnd Millennium B.C. and Iron Age; yet due to the lack of sufficient surface material, it is not possible to have a more precise dating. The first construction phase of the tower must be earlier than the arrivals of Urartians. Yet, it may be considered that the tower was also in use in later periods which should be confirmed by future excavations.

Another archaeological area is determined 180 $m$ south of Ölçek Tower on a mound in Ziyaret Tepe. A small group of pottery sherds similar to the finds from Ölçek Tower were observed on this höyük site which is about $20 \times 17 \mathrm{~m}$ in size. In the northern edge of the area there is also a pile of stones that could indicate to a burial. During its usage time there was a wall surrounding the mound completely which is ruined today. We cannot directly relate this archaeological site with Ölçek Tower due to the lack of sufficient surface data.

\section{KOCAKÖY TOWER}

Kocaköy Tower is located $7 \mathrm{~km}$ southeast of the central district of Ardahan by highway. This tower situates on a mound with an elevation of $2171 \mathrm{~m}$ and it stands 700 m west of Kocaköy (Map 1). The construction is located at a point which displays a smooth vision in southern direction and it must have been served as a watchtower. The tower is constructed with cyclopean stones in drywall technique and has a square plan of a size of $7.6 \times 7.6 \mathrm{~m}$ (Fig. 21-22). One of the cyclopean stones belonging to the tower is about $2.1 \times 1 \mathrm{~m}$ in size and others on the better preserved southern side rank as $1.8 \times 1 \mathrm{~m}$ or $1.3 \times 1.1 \mathrm{~m}$. Maximum preserved height of the tower's wall is $1.5 \mathrm{~m}$ (Fig. 23) and the entrance of the building was probably at the northwest edge. A properly cut stone of $70 \times 70 \mathrm{~cm}$ in size was probably used as a lintel. A few pottery sherds collected do not offer any exact date. However, it should have been in use beginning from the Second Millennium B.C. to the Early Iron Age and later.

\section{RESULTS OF THE 2015 SURVEY CAMPAIGN}

M. Işıklı indicates in his book about the Early Transcaucasian culture that settlements in lowlands and valleys inhabited by the early agriculturist communities of the Eneolithic period in Transcaucasia were substantially abandoned and the highland begun to be settled within the Early Bronze Age ${ }^{4}$. There is a good probability that the highland settlements were seasonally inhabited especially in a region like Ardahan where winter conditions are mostly hard. Our surface fieldwork in Ardahan evidenced the indications of pastoral communities. Işıklı also emphasizes that the seasonal settlements in highland hillsides of Transcaucasia are not encountered in Eastern Anatolia in general with some exceptions ${ }^{5}$. Yet, the archaeological sites that we discovered in the highlands in the northern and southern parts of Ardahan plain, seem not to follow this determination. Compared to the highland ones archaeological sites in the lower plains of Ardahan are less in numbers, although it is still too early to create definite evolutions about the archaeology of the central district of Ardahan.

A distinguished feature that can be observed in the settlements of Ardahan is the row of walls that surrounds these archaeological sites. This particular situation is not dominant in Eastern Anatolia or in Transcaucasian landscapes. Existence of defensive or boundary walls is known in a few number of Early Bronze Age sites in Transcaucasia which are Khizanaant Gora in Shida Kartli of Georgia ${ }^{6}$, Shengavit in Yerevan, Armenia ${ }^{7}$, Garni, a major village in Kotayk Province of Armenia ${ }^{8}$ and Yanik Tepe, about $20 \mathrm{~km}$ from Tabriz in northwestern Iran ${ }^{9}$. The fortified high plateau site of Ziyaret Tepe in Değirmenli with Early Transcaucasian pottery finds (Fig. 24), has two boundary walls. In Sulakyurt, another central district village, there are two archaeological find spots which are located in a distance of $900 \mathrm{~m}$ to each other and the southern one offers plenty of Early Transcaucasian pottery sherds. At least, northern and eastern edges of this site are surrounded with a row of wall (Fig. 25). These walls are not solid or monumental as typical defensive walls; yet they should have served as preserving and assigning the borders of the site.
4) Iş1kl1 2011: 98. Also $c f$. Smith 2005: 259.
5) Iș1klı 2011: 99
6) Işıklı 2011: 82; Sagona 1984: 40-41
7) Burney and Lang 1971: 57; Iș1klı 2011: 85-86.
8) Kushnareva 1997: 59.
9) Burney and Lang 1971: 62. Summers 2014: 165, 167; 2013. 


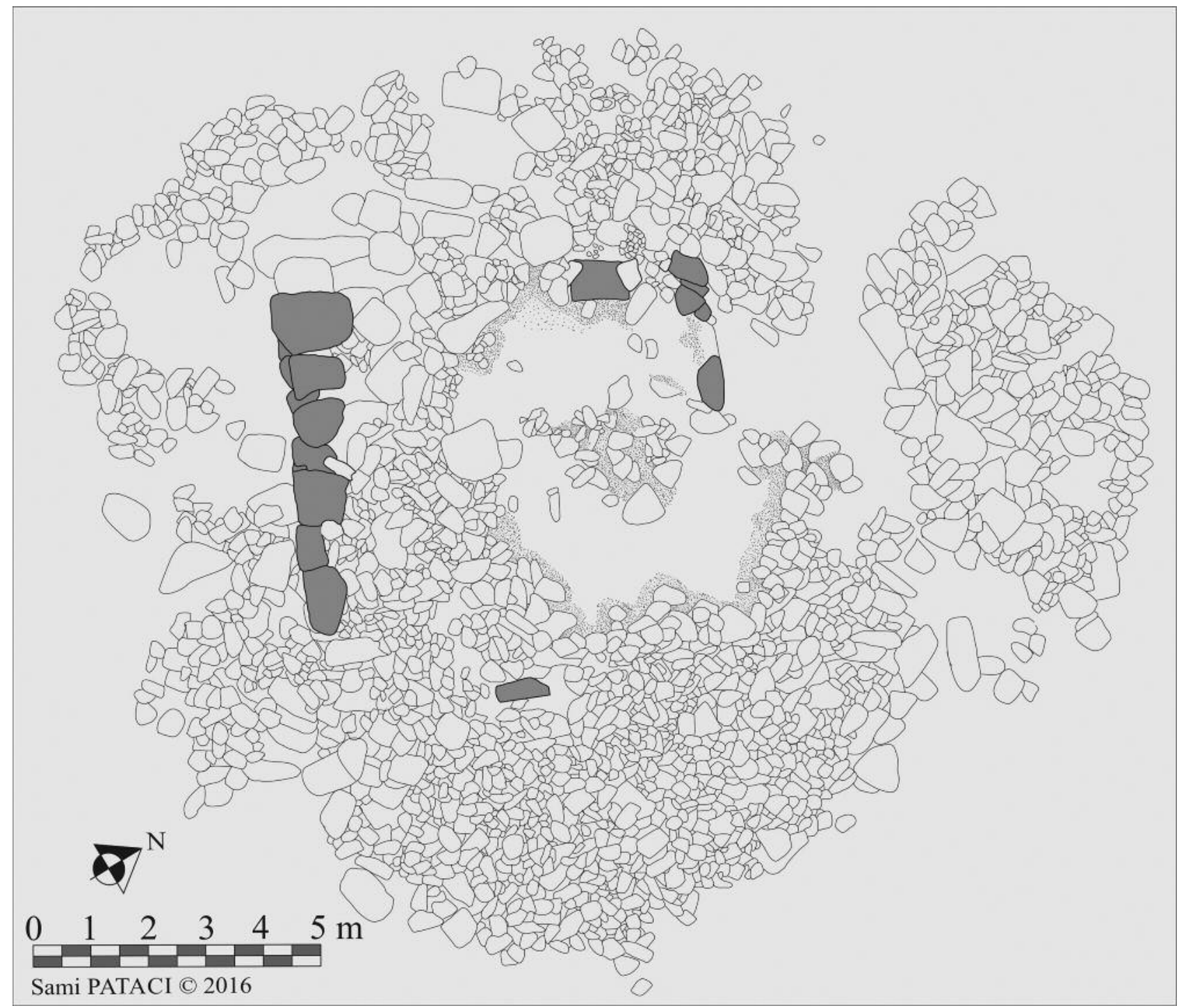

Fig. 22 : Plan of the Kocaköy Tower (S. Patac1, 2016).

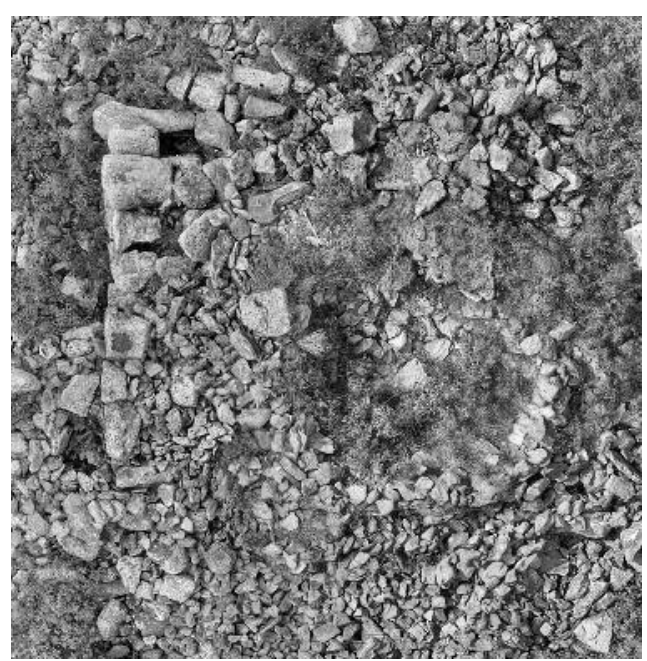

Fig. 21 : Aerial photography of the Kocaköy Tower (S. Patac1, 2015).

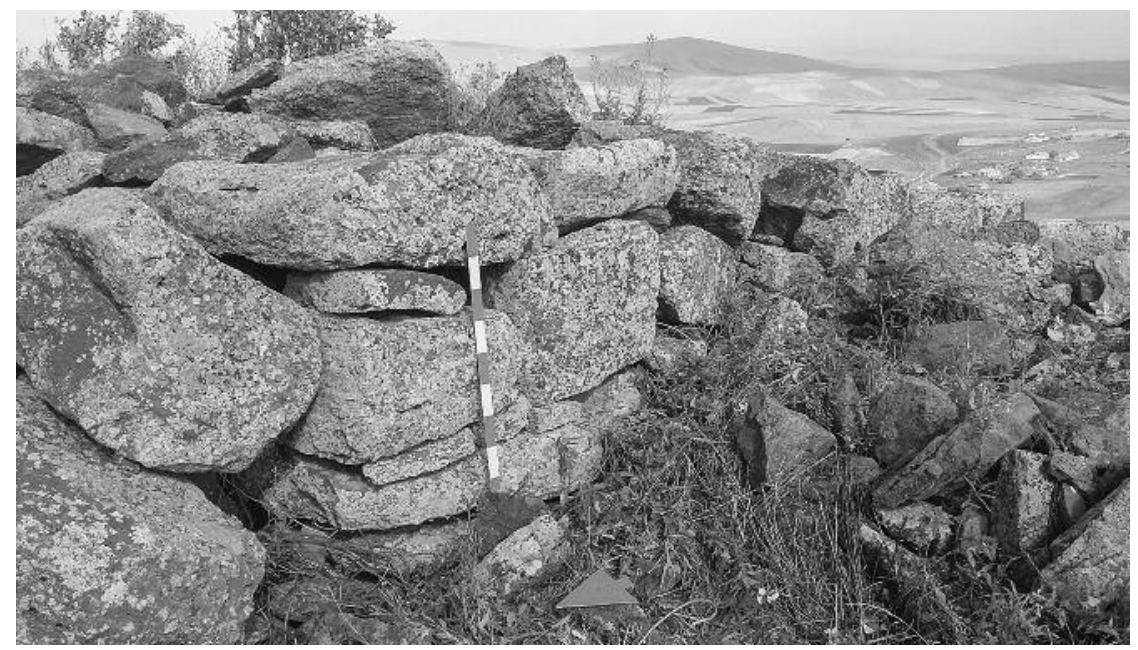

Fig. 23 : Masonry of the Kocaköy Tower (S. Patac1, 2015) 

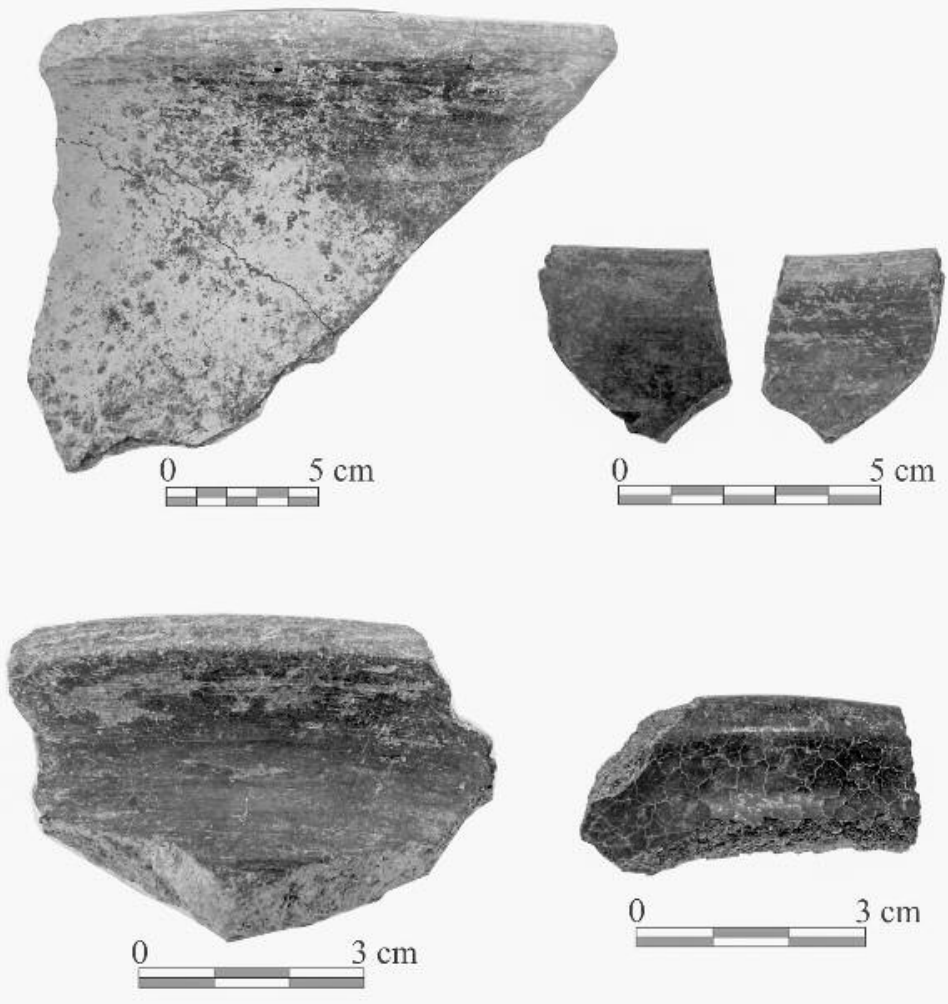

Fig. 24 : Pottery finds from the fortified high plateau site at Değirmenli (S. Patac1, 2015).
Fig. 25 : Plan of the Early Transcaucasian site at Sulakyurt (S. Patac1, 2016).

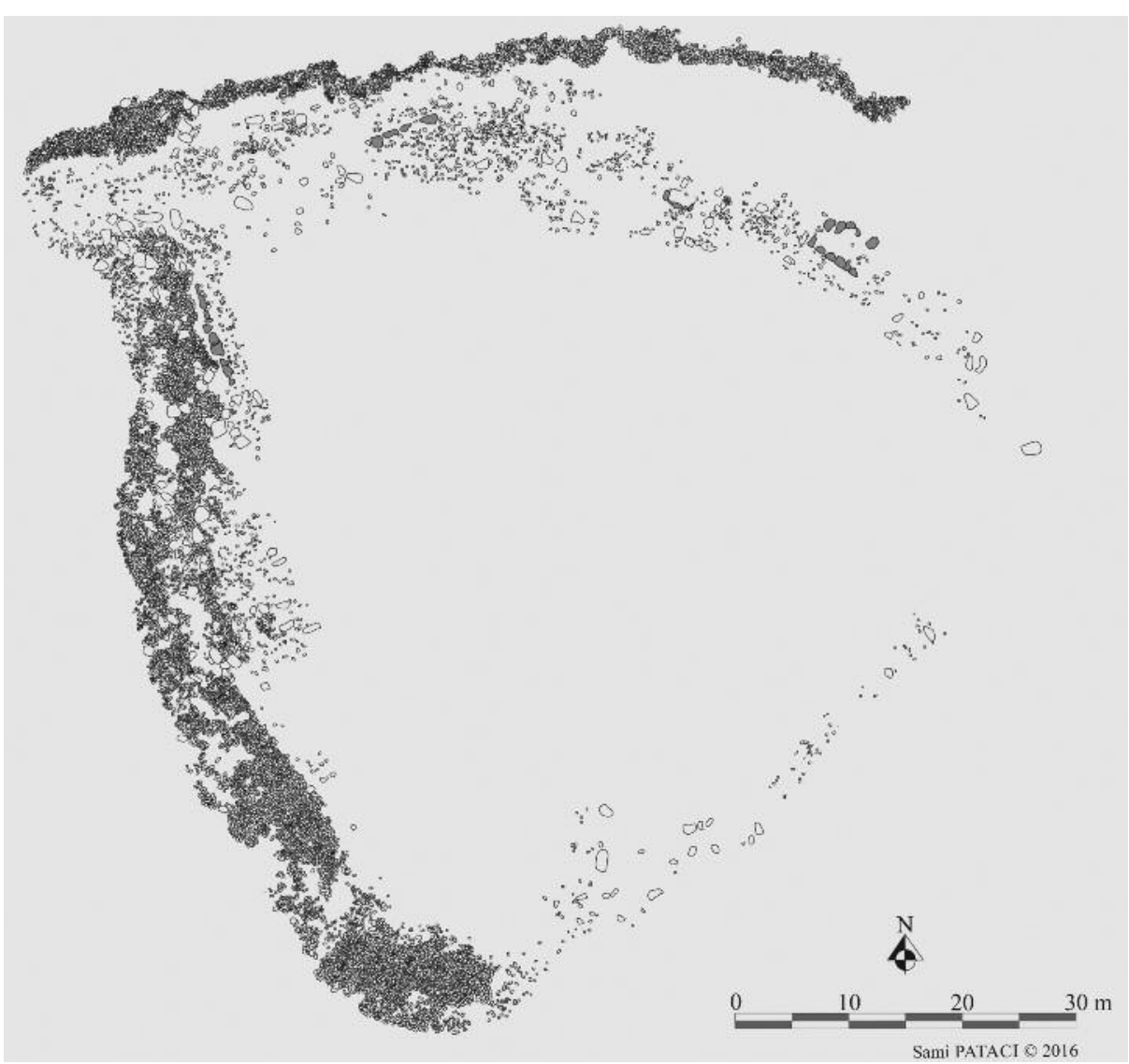


The high plateau sites discovered by us are Çeğilli-Büyük Tepe, Değirmenli-Ziyaret Tepe, two separate archaelogical sites in Sulakyurt, Kartalp1nar-Tekdoruk Tepe and Ziyaret Tepe in Alagöz, called same as the one in Değirmenli ${ }^{10}$. Some common features of these sites attract our attention: They are found in a high ground, between altitudes of 2000-2500 m and placed on peaks of the hills which are normally terraced. Even on the site of Değirmenli-Ziyaret Tepe three layers of terracing can be seen from its peak to the foothills. All of these high plateau sites have boundary walls except the one in Alagöz. On the site of Degirmenli-Ziyaret Tepe there is a rotundate tower in the center of the terrace (Fig. 26). Archaeological surface finds indicate that there had been round planned buildings on Çeğilli-Büyük Tepe and also Kartalpınar-Tekdoruk Tepe; yet these structures are ruined in the course of time and only their rubble remains. As it is aforementioned, in Sulakyurt there are two separate high plateau sites. The southern one does not have a tower; yet the northern one located on a higher hill has a rotundate tower on its southern edge (Fig. 27). The walls and the towers of these archaeological sites have been built by drywall technique. Small or medium sized and poorly worked stones have been used for the walls. Early Transcaucasian pottery was found only on Değirmenli-Ziyaret Tepe and southern site of Sulakyurt. Yet, other highland sites do not have enough small finds for a more accurate dating; systematic excavations would provide clearer data. Common features of these high plateau sites and the areas between them make us to think that these find spots should belong to the same period.

Comparing to others the site of Alagöz houses a distinctive architecture which features a horseshoe plan. On the north wall of this site there are small and half-round formed architectural elements. In addition, two side by side round structures exist just a few meters of this site. The site is on the peak of a high hill with an altitude of $2500 \mathrm{~m}$ and beside of the architectural remains no archaeological finds can be observed on the land level.

An archaeological site is determined north of Kartalpinar Village which is dated to the Second Millennium B.C. Compared to other ones in the central district of Ardahan this site has a distinctive and complicated structure. In addition, the area just north of the site was in use as burial grounds. Kartalpınar is the most important site in the region in the regards of its extensive evidence of burial customs of the Second Millennium B.C.

In the past three survey seasons the number of Early Iron Age finds is lower than the Bronze Age finds. In some places there is only a few or even sometimes no small finds of the Iron Age; because of this it is difficult to assign these sites to any relevant periods. The current stage of conclusion is put forward that in Ardahan a clearer distinction between the archaeological artefacts of the Second Millenium B.C. and Early Iron Age is not definable yet. But it is highly possible to assume that some Bronze Age sites were still in use during the Early Iron Age.

K. Köroğlu who surveyed the area in preceding years, documented some small finds dating to the Iron Age in Tepeler Höyük, which is visited by us in 2013. Small finds from this höyük site is consisted of a small portion of red-slipped Urartian ware ${ }^{11}$. Again in 2011, a small amount of Iron Age pottery was documented in an area that is located $200 \mathrm{~m}$ east of the village Çimenkaya and $19 \mathrm{~km}$ of Ardahan city district. The absence of Urartian evidences in our previous surveys in Ardahan made us to think that Ardahan plain had an isolated and local position during the period of Urartians. The Urartian inscriptions recovered in Ortakent and Taşköprü in preceding years cannot prove that Ardahan was included in the cultural boundary of the Urartian Kingdom. Due to the small amount of archaeological data one can assume that Ardahan was meaning a tribute and pillaging zone, rather than a residential area for the Urartian Kingdom.

\section{A Note and Acknowledgements}

All the maps and photos were made by S. Patac1 in 2015 and 2016. We would like to thank to $\mathrm{Mr}$ Kerim Özgür Özgen (Izmir) and Ms Nihal Kardoruk (Izmir) for the reading this text. We also would like to express our deepest gratitude to Mr Aksel Tibet (Istanbul) for accepting this report to Anatolia Antiqua.

S.P. and E.L. 


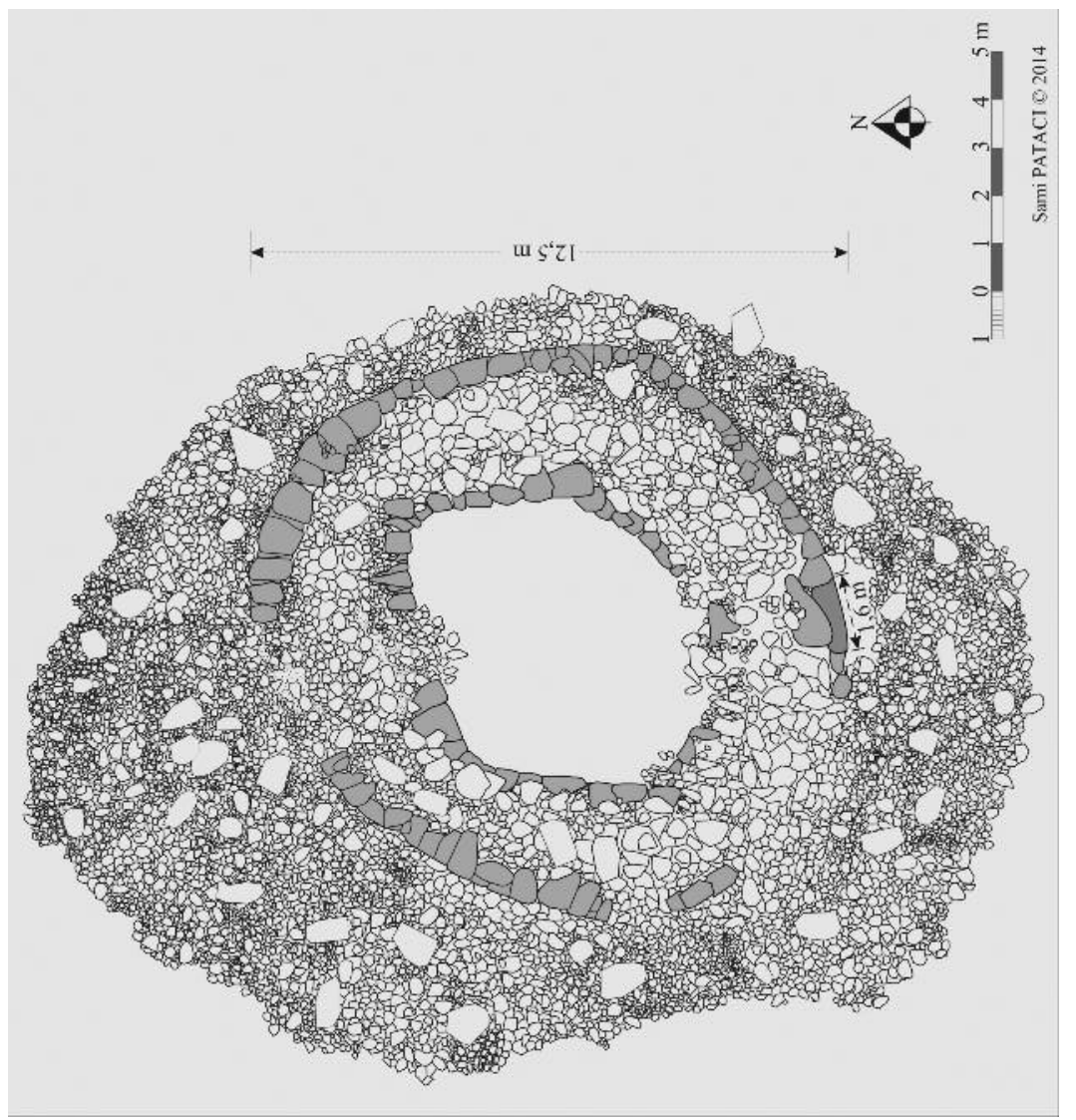

है

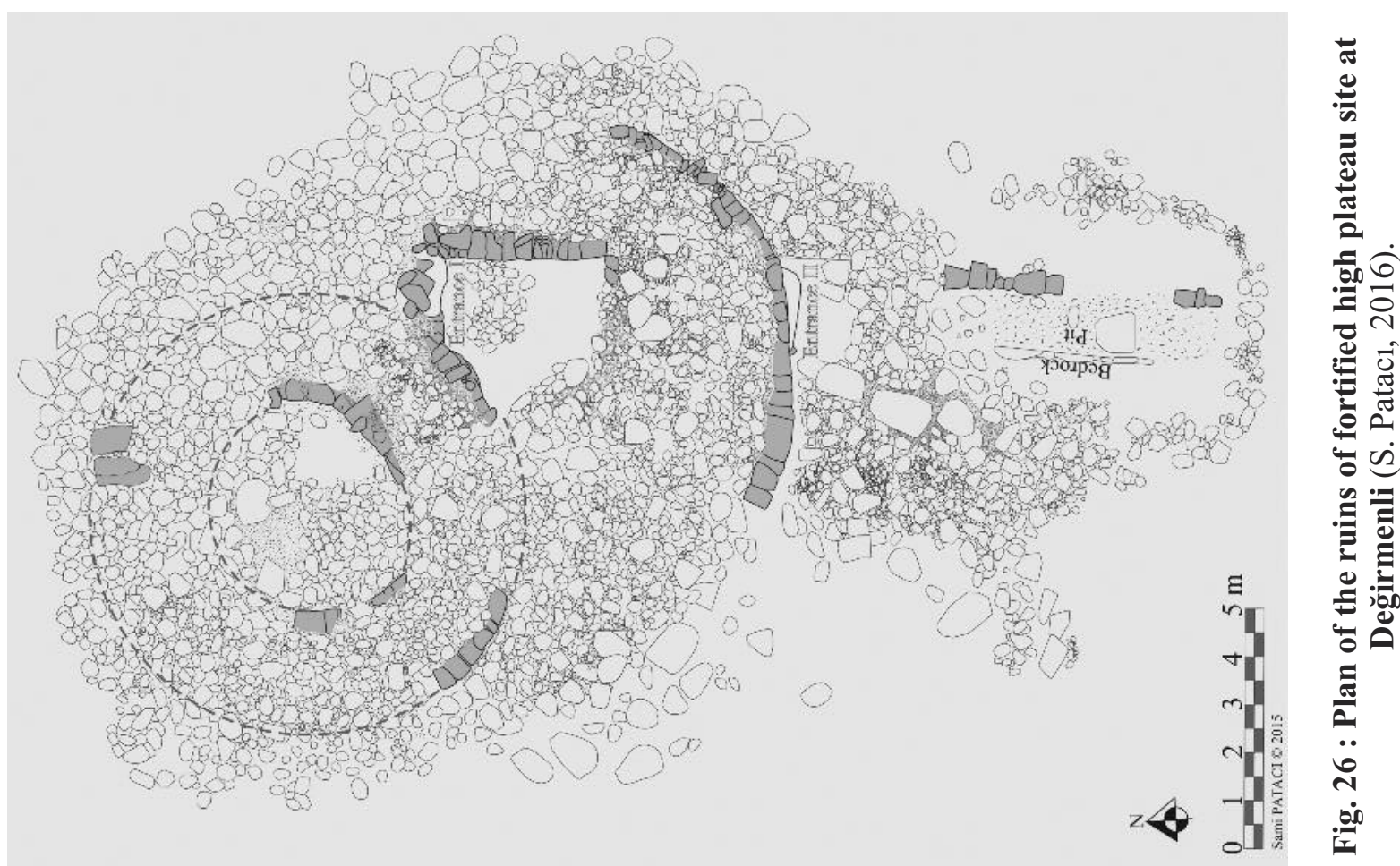




\section{ABBREVIATIONS AND BIBLIOGRAPHY}

Burney, C. and Lang, D.M., 1971: The Peoples of the Hills: Ancient Ararat and Caucasus, London.

Gündoğdu, H., 2000: Kaleler ve Kuleler Kenti Ardahan, T.C. Ardahan Valiliği Kültür Yayınları No: 4, Ankara.

Güneri, S., 1992: “Doğu Anadolu’da Yeni Gözlemler”, Türk Arkeoloji Dergisi 30: 149-196.

Iş1kl1, M., 2011: Doğu Anadolu Erken Transkafkasya Kültürü: Çok Bileşenli Gelişkin Bir Kültürün Analizi, Arkeoloji ve Sanat Yayınları, Istanbul.

Köroğlu, K., 2001: “Urartu Krallığı'nın Kuzey Yayılımı ve Qulha Ülkesinin Tarihi Coğrafyası”, Belleten 64/241: $717-741$

- 2005: "The Northern Border of the Urartian Kingdom", in Çilingiroğlu, A. and Darbyshire, G. (eds.), Anatolian Iron Ages 5, Proceedings of the Fifth Anatolian Iron Ages Colloquium held at Van, 6-10 August 2001, British Institute of Archaeology at Ankara, Monograph 31, London: 99-106.

Kushnareva, K.Kh., 1997: The Southern Caucasus in Prehistory: Stages of Cultural and Socioeconomic Development from the Eighth to the Second Millennium B.C., Translated by H. N. Michael, University Museum Monograph 99, Philadelphia, PA.
Patac1, S., 2014: “Ardahan İli 2013 Y1lı Arkeolojik Yüzey Araştırması”, in AST 32/1: 99-116.

- 2015a: "Transkafkasya Arkeolojisi Kapsaminda Ardahan", Yeni Türkiye 72/2 (=Kafkaslar Özel Sayısı): 52-86.

- 2015b: "Archaeological Surveys of Ardahan in Northeastern Anatolia in 2013", in Lafl1, E. and Patac1 S. (eds.), Recent Studies on the Archaeology of Anatolia, British Archaeological Reports, International Series 2750, Oxford: 467-480.

Patac1, S. and Lafl, E., 2015: "Surveys in Ardahan on the Turkish-Georgian Borderline in 2013 and 2014", Anatolia Antiqua XXIII: 229-248.

Sagona, A.T., 1984: The Caucasian Region in the Early Bronze Age, Part 1-3, British Archaeological Reports, International Series 214, Oxford.

Smith, A.T., 2005: "Prometheus Unbound: Southern Caucasia in Prehistory", Journal of World Prehistory 19/4: 229-279.

Summers, G.D. 2013: Yanik Tepe, Northwestern Iran: The Early Trans-Caucasian Period. Stratigraphy and Architecture, Leuven.

- 2014, "The Early Trans-Caucasian Culture in Iran: Perspectives and Problems", Paléorient 40/2: 155-168. 


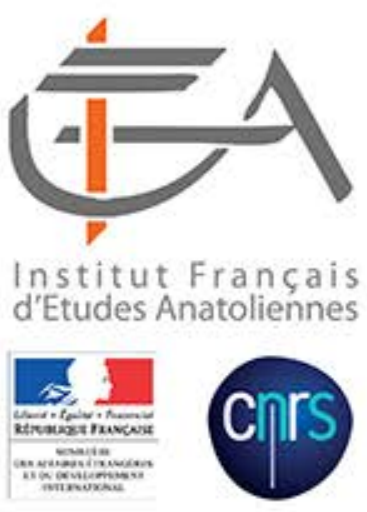

Eurômos : le temple de Zeus vu de l'Est (cliché Sönmez Alemdar).

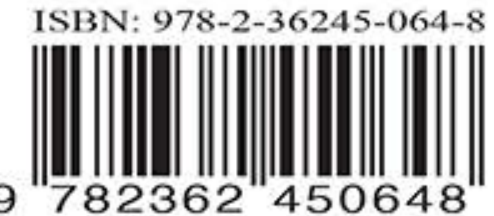

